2. Указ Президента Российской Федерации № 204 от 7 мая 2018 г. «О национальных целях и стратегических задачах развития Российской Федерации на период до 2024 года». URL: http://www.garant.ru/products/ipo/prime/ doc/71837200/ (дата обращения: 02.09.2019).

3. Вахрушева Е. В., Крапивина К. Н. Изменения в системе национального российского образования // Молодой ученый. 2013. № 1 (48). С. 326-328.

4. Государственная программа «Развитие образования» на 2018-2025 гг. URL: http://static.government.ru/media/files/ 313b7NaNS3VbcW7qWYsIEDbPCuKi6IC6.pdf (дата обращения: 02.09.2019).

5. Авралев Н. В., Ефимова И. Н., Маковейчук А. В. Политические основы трансформации современного российского высшего образования в контексте глобализации // Теории

УДК 378

Науч. спец. 13.00.08

DOI: 10.36809/2309-9380-2019-24-127-129

\section{РЕАЛИЗАЦИЯ ОБЩЕКУЛЬТУРНЫХ КОМПЕТЕНЦИЙ МЛАДШИХ КУРСОВ ЧЕРЕЗ ПРОВЕДЕНИЕ НЕДЕЛИ КАФЕДРЫ}

В статье описан вариант реализации общекультурных компетенций младших курсов через проведение внеаудиторного мероприятия «Неделя кафедры общеобразовательных дисциплин». Представлены его результаты.

Ключевые слова: общекультурные компетенции, образовательная программа бакалавров, внеаудиторные мероприятия, неделя кафедры, предметная олимпиада, практикоориентированные учебные действия, семинар, конкурс. и проблемы политических исследований. № 5А. Т. 7. 2018. С. 266-273.

6. Ефимова И. Н., Маковейчук А. В. Анализ влияния роли рейтинговых позиций вуза на мотивацию абитуриентов при выборе места обучения: прикладной аспект // Вестн. Перм. ун-та. Философия. Психология. Социология. Вып. 1(17). 2014. С. 173-181.

7. Образование через всю жизнь: профориентация до вуза и в вузе. Опыт ННГУ им. Н. И. Лобачевского / Н. В. Авралев, Т. Н. Беспалова, Р. Г. Стронгин, Е. В. Чупрунов ; под ред. Р. Г. Стронгина. Нижний Новгород : Изд-во ННГУ им. Н. И. Лобачевского, 2019. 180 с. 2019

(C) Авралев Н. В., Ефимова И. Н., Маковейчук А. В.,

\title{
IMPLEMENTATION OF CULTURAL COMPETENCES OF FRESHMEN THROUGH THE WEEK OF THE DEPARTMENT
}

The article describes the implementation of the general cultural competences of junior courses through an extracurricular event "Week of the Department of General Disciplines". Its results are presented.

Keywords: general cultural competence, educational program of bachelors, extracurricular activities, subject olympiad, week of the department, practice-oriented educational actions, seminar, competition.

Главной целью подготовки бакалавров по направлению «Агрономия» является необходимость получения прочных профрессиональных знаний, на основе которых возможна долговременная инициатива самостоятельного обучения и успешная социальная мобильность.Требованием к результатам освоения программы сегодня становятся компетенции.

Целью нашего исследования является реализация общекультурных компетенций младших курсов через проведение «Недели кафедры общеобразовательных дисциплин».

Для достижения цели решаются следующие задачи: выделить общекультурные компетенции по направлению подготовки бакалавров «Агрономия» и показать способ реализации общекультурных компетенций младших курсов через проведение «Недели кафредры общеобразовательных дисциплин».

В результате освоения образовательной программы бакалавриата у выпускника должны быть сформированы общекультурные, общепрофессиональные и профессиональные компетенции [1]. На 1-х и 2-х курсах обучения становится очевидной реализация (в той или иной мере) общекультурных компетенций, чему способствует освоение дисциплин (модулей) по философии, истории, иностранному языку, русскому языку и культуре речи, правоведению, безопасности жизнедеятельности, которые реализуются в рамках базовой части блока 1.

В стандарте ФГОС ВО по направлению подготовки 35.03.04 «Агрономия» указывается, что выпускник, освоивший программу бакалавриата, должен обладать следующими общекультурными компетенциями, представляющими способности:

- использовать основы философских знаний для формирования мировоззренческой позиции (ОК-1);

- анализировать основные этапы и закономерности исторического развития общества для формирования гражданской позиции (ОК-2);

- использовать основы экономических знаний в различных сферах жизнедеятельности (ОК-3);

- применять основы правовых знаний в различных сфрерах жизнедеятельности (ОК-4);

- осуществлять коммуникацию в устной и письменной формах на русском и иностранном языках для решения задач межличностного и межкультурного взаимодействия (OK-5); 
- работать в коллективе, толерантно воспринимать социальные, этнические, конфессиональные и культурные различия (ОК-6);

- совершать самоорганизацию и самообразование (ОК-7);

- применять методы и средства фризической культуры для обеспечения полноценной социальной и профрессиональной деятельности (ОК-8);

- использовать приемы оказания первой помощи, методы защиты в условиях чрезвычайных ситуаций (ОК-9) [1].

Одной из форм организации внеаудиторной работы со студентами в Октемском филиале Якутской государственной сельскохозяйственной академии является «Неделя кафедры общеобразовательных дисциплин». При ее организации мы исходим из того, что обучение профессии должно быть практико-ориентированным, мотивированным и понятным студентам с первых дней учебы [2]. Первым мероприятием стало открытие «Недели кафедры», где младшим курсам был представлен профессорско-преподавательский состав филиала и кафедры, а также дисциплины учебного плана. Студенты старших курсов показали презентации об учебном и внеучебном процессе, возможности реализовать себя в общественной жизни учебного заведения, о порядке работы подразделений учебного заведения.

План мероприятий приведен в таблице.

Общекультурные компетенции развиваются с первых дней учебы в вузе, поэтому следующим мероприятием ста- ли предметные олимпиады для 1-х и 2-х курсов. Целью предметных олимпиад является совершенствование качества подготовки бакалавров, а также повышение интереса студентов к дисциплинам естественно-научного, гуманитарного и социально-экономического циклов. Задачами олимпиады являются выявление одаренной молодежи и формирование команды студентов, способных представлять филиал в олимпиадах различного уровня по дисциплинам естественно-научного, гуманитарного, социально-экономического цикла, а также реализация общекультурных компетенций.

Олимпиады проводятся по математике, иностранному языку, информатике, русскому языку и культуре речи, химии, основам философии, истории в 2 тура: первый, внутригрупповой, проводится преподавателями среди студентов, обучающихся по указанным дисциплинам, второй тур - среди студентов, занявших призовые места в первом туре.

Следующим мероприятием стал конкурс социальных проектов, посвященный году волонтерства «Мир меняют Люди» для 1-х и 2-х курсов. Цель проектов - выявление и развитие социальной активности и творческого потенциала обучающихся.

Задачи:

- привлечение внимания обучающихся к решению актуальных социально-значимых проблем общества;

- развитие навыков разработки и реализации проектов;

- привитие навыков публичного выступления у студентов.

План недели кафедры общеобразовательных дисциплин

\begin{tabular}{|c|c|}
\hline Дата & Мероприятие \\
\hline & Открытие недели кафредры \\
\hline День 1 & $\begin{array}{l}\text { 1-й тур предметных олимпиад } \\
\text { Олимпиада по математике } \\
\text { Олимпиада по английскому языку } \\
\text { Олимпиада по физике } \\
\text { Олимпиада по русскому языку } \\
\text { Олимпиада по химии } \\
\text { Олимпиада по истории } \\
\text { Олимпиада по основам философии } \\
\text { Олимпиада по физической культуре } \\
\text { Семинар по ораторскому искусству }\end{array}$ \\
\hline День 2 & $\begin{array}{l}\text { 2-й тур предметных олимпиад } \\
\text { Олимпиада по математике } \\
\text { Олимпиада по английскому языку } \\
\text { Олимпиада по физике } \\
\text { Олимпиада по русскому языку } \\
\text { Олимпиада по химии } \\
\text { Олимпиада по истории } \\
\text { Олимпиада по основам фрилософии } \\
\text { Олимпиада по физической культуре } \\
\text { Выставка-конкурс студенческих работ по математике и оценке недвижимого имущества }\end{array}$ \\
\hline День 3 & $\begin{array}{l}\text { Конкурс социальных проектов, посвященный году волонтерства «Мир меняют Люди» } \\
\text { Встреча-семинар на тему «Исследователь - строитель будущего» }\end{array}$ \\
\hline День 4 & $\begin{array}{l}\text { Интеллектуальная игра } \\
\text { «Татьянин день - день студента» } \\
\text { Культурная программа } \\
\text { Дискотека }\end{array}$ \\
\hline
\end{tabular}


Тематика проектов:

1) социальное волонтерство;

2) благоустройство;

3) социальная помощь;

4) поддержка спорта и 30ж;

5) поддержка семьи;

6) молодежная политика;

7) наука и образование;

8) культура;

9) экология;

10) благотворительность.

Критерии оценивания: актуальность проекта; полнота представления проекта; проработанность и обоснованность проектных шагов; соответствие целей и задач ожидаемым результатам; целостность и сохранение общей логики работы; соблюдение регламента выступления. Победители участвуют в конференциях, проводимых вузом, готовят материалы для публикаций. Традиционными на неделе кафедры стали встречи с интересными людьми, например встреча-семинар на тему «Исследователь - строитель будущего». Семинар позволил студентам и углубить навыки работы в текстовом редакторе, и освоить правила оформления пояснительных записок и графической части проектов.

Заключительным мероприятием «Недели кафедры общеобразовательных дисциплин» стал «День студента», целью которого была попытка реализации общекультурных компетенций младших курсов через внеаудиторные мероприятия. В последние годы «Неделя кафредры» стал традиционным долгожданным мероприятием для студентов, подготовкой заданий к которому занимается большая часть профессорско-преподавательского состава (далее ППС) кафедры.

УДК $37.03,378$

Науч. спец. 13.00.08

DOI: 10.36809/2309-9380-2019-24-129-131

\section{АКТУАЛЬНЫЕ АСПЕКТЫ МЕТОДИКИ ОВЛАДЕНИЯ ПРОФЕССИОНАЛЬНЫМИ ЗНАНИЯМИ БУДУЩИМИ ОФИЦЕРАМИ РОСГВАРДИИ}

В статье рассматривается целесообразность применения теоретических знаний, сопряженных с практическим боевым опытом офицеров-наставников, передаваемым в ходе образовательной деятельности. Анализируется выбор и применение наиболее актуальных форм, методов, способов и приемов овладения профессиональными знаниями и умениями с учетом специфики выполнения предстоящих задач.

Ключевые слова: профессиональное образование, приемы и способы, активные формы обучения, офицеры войск национальной гвардии Российской Федерации, образовательная деятельность.
Как показал опыт проведения конкурса проектов, выбранная форма его проведения способствует активизации учебного процесса, формированию студенческого сообщества и профессионального сообщества студентов и преподавателей. Нельзя сказать, что в такой форме организации есть принципиальное новшество, мероприятия, входящие в ее программу, являются общеизвестными и используются повсеместно. Тем не менее «Неделя кафедры» позволяет синхронизировать работу по подготовке молодых специалистов, проведению открытых занятий, учебно-методической работы преподавателей, привлечению абитуриентов:

- ППС получает возможность ранней ориентации студентов на тему выпускной квалификационной работы и научную работу;

- ППС реализует общекультурные компетенции не только на занятиях, но и через внеаудиторные мероприятия.

Проведенная работа позволяет повысить показатели научно-исследовательской работы студентов, профессорско-преподавательского состава, кафедры и образовательного учреждения в целом.

1. Приказ Министерства образования и науки РФ от 26 июля 2017 г. № 699 «Об утверждении федерального государственного образовательного стандарта высшего образования - баклавриат по направлению подготовки 35.03.04 Агрономия». URL: https://www.garant.ru/products/ ipo/prime/doc/71644342/ (дата обращения: 02.09.2019).

2. Олесова М. М. Применение практико-ориентированных технологий обучения в вузе // Филологические науки. Вопросы теории и практики. 2017. № 7(73). Ч. 2. С. 201-204.

(C) Афанасьева С. Р., Олесова М. М., 2019

\section{RELEVANT ASPECTS OF MASTERING PROFESSIONAL KNOWLEDGE BY FUTURE OFFICERS OF FEDERAL NATIONAL GUARD TROOPS SERVICE}

The article discusses the appropriateness of applying theoretical knowledge coupled with practical combat experience of mentor officers transmitted in the process of educational activity. It analyses the selection and application of the most relevant forms, methods, means and techniques for mastering professional knowledge and skills, taking into account the specifics of the forthcoming tasks.

Keywords: professional education, techniques and methods, active forms of training, officers of the National guard of the Russian Federation, educational activity.
На современном этапе развития нашего общества при рефрормировании силовых структур, модернизации систем воо- ружения и постоянно возрастающих требованиях к квалификации военных специалистов вопрос повышения компетентности 